\title{
PENGARUH PENGUNGKAPAN CORPORATE SOCIAL RESPONSIBILITY TERHADAP COST OF EQUITY PERUSAHAAN
}

\author{
Mitta Ariyani \\ Alumni Fakultas Ekonomika dan Bisnis Universitas Kristen Satya Wacana \\ Yeterina Widi Nugrahanti \\ Fakultas Ekonomika dan Bisnis Universitas Kristen Satya Wacana \\ yeterina.nugrahanti@staff.uksw.edu
}

\begin{abstract}
The purpose of this study is to investigate the effect of Corporate Social Responsibility (CSR) Disclosure on Cost of Equity Capital. CSR disclosure index is measured based on Global Reporting Initiative standards, while Cost of Equity Capital is measured by Capital Asset Pricing Model (CAPM). This study uses manufacturing companies which is listed on Indonesia Stock Exchange (IDX) in 2010. By purposive sampling, this research obtained 72 companies as a samples. The control variables used are financial leverage and firm size. Multiple regression analysis by SPSS 16 was run for testing the hypothesis. The result show that CSR disclosure and financial leverage have no effect to Cost of Equity. Then, firm size have positive effect to Cost of Equity.
\end{abstract}

Keywords: Corporate Social Responsibility (CSR) disclosure, cost of equity, financial leverage, firm size

\section{PENDAHULUAN}

Tanggung jawab sosial perusahaan (CSR) telah menjadi semakin penting dalam beberapa tahun terakhir karena pertumbuhan dramatis dalam jumlah lembaga, reksa dana, dan sumber daya online dan publikasi lain yang mengkhususkan diri dalam mendorong perusahaan untuk memperbaiki praktekpraktek mereka menurut berbagai kriteria tanggung jawab (Bassen et al., 2006).

Untuk terus going concern perusahaan sebaiknya melaksanakan kegiatan yang berdampak positif. Tetapi kegiatan operasi yang berdampak negatif seringkali tidak bisa dihindari. Sebagai contohnya pada tahun 2010 terjadi kebijakan moratorium kepada PT Mega Prima Persada karena pengelolaan limbah buruk bagi masyarakat. Melubernya lumpur dan gas panas di Kabupaten 
Sidoarjo yang disebabkan eksploitasi gas PT Lapindo Brantas, dan kasus pengubahan lahan hutan menjadi perkebunan kelapa sawit yang melibatkan PT Andika Pratama Sawit Lestari (APSL). Kegiatan perusahaan yang berdampak negatif menimbulkan masalah lingkungan dan sosial yang akhirnya akan mengancam keberlanjutan operasional perusahaan. Mengingat hal tersebut maka penting bagi perusahaan untuk turut serta menjaga dan peduli terhadap aspek lingkungan baik itu masyarakat maupun lingkungan alam di mana perusahaan tersebut beroperasi. Konsep ini kemudian berkembang dengan istilah Corporate Sosial Responsibility (CSR) atau tanggung jawab sosial perusahaan.

Definisi CSR menurut Darwin (2004) adalah mekanisme bagi suatu organisasi untuk secara sukarela mengintegrasikan perhatian terhadap lingkungan dan sosial ke dalam operasinya dan interaksinya dengan stakeholders, yang melebihi tanggung jawab organisasi di bidang hukum. Di Indonesia CSR diatur dalam UU Perseroan Terbatas (PT) No 40 tahun 2007, disebutkan bahwa PT yang menjalankan usaha di bidang dan atau bersangkutan dengan sumber daya alam wajib menjalankan tanggung jawab sosial dan lingkungan (Pasal 74 ayat 1).

Tetapi kenyataannya di Indonesia, CSR masih dianggap tidak penting atau biasanya menjadi hal yang disepelekan dan dijalankan dengan setengah hati. CSR dijalankan hanya untuk mendapatkan perhatian masyarakat. Sampai saat ini tingkat pelaporan dan pengungkapan CSR di Indonesia masih relatif rendah, sehingga belum terdapat kesepakatan standar pelaporan CSR yang dapat dijadikan acuan bagi perusahaan dalam menyiapkan laporan CSR (Utama, 2007).

Menurut Rosmasita (2007) peran penting CSR terhadap perusahaan, antara lain: a) Untuk mempertahankan dan meningkatkan citra perusahaan; b) Untuk membebaskan akuntabilitas organisasi atas dasar asumsi adanya kontrak sosial di antara organisasi dan masyarakat; c) Untuk memberikan informasi kepada investor.

Menurut Surat Keputusan BAPEPAM No. Kep-38/PM/1996, pengungkapan informasi dapat dikelompokkan menjadi dua, yaitu pengungkapan wajib (mandatory disclosure) dan pengungkapan sukarela (voluntary disclosure). Perusahaan yang melakukan pengungkapan CSR biasanya mengungkapan dalam laporan tahunan. Pengungkapan CSR termasuk bagian dari pengungkapan sukarela. Penelitian-penelitian terdahulu mengenai pengaruh pengungkapan sukarela terhadap cost of equity pernah dilakukan antara lain penelitian yang dilakukan oleh Botosan (1997), Mardiyah (2002), Murni (2003), dan Francis, Nanda dan Olsson (2005). Mereka menemukan bahwa tingkat pengungkapan sukarela berpengaruh negatif terhadap cost of equity (COE). Tetapi penelitian yang dilakukan oleh Amurwani (2006) yang hasilnya bahwa pengungkapan sukarela tidak berpengaruh terhadap cost of equity (COE) perusahaan. 
COE di sini mengacu pada biaya yang dikeluarkan perusahaan untuk menarik investor agar menanamkan sahamnya ke perusahaan. Dalam penelitian yang dilakukan oleh Dhaliwal, Zhen Li, dan Tzang (2011), Gregory dkk. (2010), Sadok El Ghoul dkk. (2010) menemukan bahwa kegiatan CSR berpengaruh negatif terhadap COE perusahaan. Tetapi penelitian yang dilakukan oleh Fajar (2008) yang hasilnya bahwa pengungkapan CSR tidak berpengaruh terhadap COE perusahaan.

Selanjutnya penelitian di Indonesia tentang pengaruh CSR terhadap cost of equity juga pernah dilakukan oleh Sasongko dan Supatmi (2008), sampel yang digunakan adalah perusahaan sektor non keuangan sebanyak 118 perusahaan yang terdaftar di BEJ tahun 2006. Variabel kontrol yang digunakan dalam penelitian tersebut adalah ukuran perusahaan dan status perusahaan. Hasil penelitian tersebut menemukan bahwa tingkat pengungkapan CSR mempunyai efek positif terhadap cost of equity perusahaan. Sedangkan ukuran perusahaan dan status perusahaan tidak berpengaruh secara signifikan terhadap cost of equity perusahaan.

Tujuan penelitian ini untuk menganalisis pengaruh pengungkapan CSR terhadap cost of equity perusahaan. Penelitian ini merupakan replikasi dari penelitian Sasongko dan Supatmi (2008). Alasan peneliti mereplikasi karena hasil penelitian Sasongko dan Supatmi menemukan bahwa pengungkapan CSR berpengaruh positif terhadap cost of equity (COE) perusahaan, sedangkan hasil penelitian Dhaliwal, Zhen Li, dan Tzang (2011), Gregory dkk. (2010), Sadok El Ghoul dkk. (2010) menemukan bahwa pengungkapan CSR berpengaruh negatif terhadap COE perusahaan. Perbedaaan penelitian ini dengan penelitian sebelumnya yaitu pada variabel kontrolnya. Di mana variabel kontrol dalam penelitian sebelumnya adalah size dan status perusahaan sedangkan dalam penelitian ini peneliti menggunakan size dan rasio leverage karena kedua variabel tersebut mempengaruhi cost of equity perusahaan (Juniarti dan Yunita, 2003). Variabel status perusahaan tidak digunakan sebagai variabel kontrol dalam penelitian ini karena variabel tersebut pada penelitian terdahulu tidak berpengaruh signifikan terhadap COE perusahaan.

Sampel perusahaan yang digunakan dalam penelitian ini adalah perusahaan manufaktur yang terdaftar di Bursa Efek Indonesia. Karena perusahaanperusahaan manufaktur lebih banyak mempunyai dampak terhadap lingkungan di sekitarnya sebagai akibat dari aktivitas yang dilakukan perusahaan (Yusrina, 2010) sehingga diperlukan untuk melakukan pengungkapan CSR.

Manfaat penelitian ini adalah (1) bagi perusahaan, berguna sebagai bahan evaluasi untuk meningkatkan kesadaran akan pentingnya melakukan pengungkapan tanggung jawab sosial, (2) bagi investor, berguna dalam proses 
pengambilan keputusan terkait dengan penanaman modalnya di perusahaan yang melakukan CSR.

\section{TINJAUAN LITERATUR DAN PENGEMBANGAN HIPOTESIS}

\section{Corporate Social Responsibility (CSR) atau Pertanggungjawaban Sosial Perusahaan}

Lako (2009) mendefinisikan tanggung jawab sosial dan lingkungan sebagai komitmen berkelanjutan dari suatu perusahaan untuk bertanggung jawab secara ekonomik, legal, etis dan sukarela terhadap dampak-dampak dari tindakan ekonominya terhadap komunitas masyarakat dan lingkungan serta proaktif melakukan upaya-upaya berkelanjutan untuk mencegah potensi-potensi dampak negatif atau risiko aktivitas ekonomi korporasi terhadap masyarakat dan lingkungan serta meningkatkan kualitas sosial dan lingkungan yang menjadi stakeholder-nya.

Ebert (2003) mendefinisikan Corporate Social Responsibility sebagai usaha perusahaan untuk menyeimbangkan komitmen-komitmennya terhadap kelompok-kelompok dan individual-individual dalam lingkungan perusahaan tersebut, termasuk didalamnya adalah pelanggan, perusahaan-perusahaan lain, para karyawan, dan investor. CSR memberikan perhatian terhadap lingkungan dan sosial ke dalam operasinya dan interaksinya dengan stakeholders yang melebihi tanggung jawab di bidang hukum (Darwin, 2004).

Penerapan CSR dalam perusahaan-perusahaan diharapkan selain memiliki komitmen finansial kepada pemilik atau pemegang saham (shareholders), juga memiliki komitmen sosial terhadap para pihak lain yang berkepentingan, karena CSR merupakan salah satu bagian dari strategi bisnis perusahaan dalam jangka panjang. Sehingga CSR perlu diungkapkan dalam perusahaan sebagai wujud pelaporan tanggung jawab sosial kepada masyarakat.

\section{Pengungkapan CSR dalam Laporan Tahunan}

Pengungkapan secara sederhana didefinisikan sebagai penyampaian informasi (the release of information). Tujuan pengungkapan menurut Securities Exchange Commision (SEC) dikategorikan menjadi dua, yaitu: 1) protective disclosure, dimaksudkan sebagai upaya perlindungan terhadap investor, dan 2) informative disclosure, bertujuan untuk memberikan informasi layak kepada pengguna laporan (Utomo, 2000).

Pengungkapan tanggung jawab sosial merupakan proses pengkomunikasian dampak sosial dan lingkungan dari kegiatan ekonomi organisasi terhadap kelompok khusus yang berkepentingan dan terhadap masyarakat secara keseluruhan (Sembiring, 2005). 
Ada 2 jenis ungkapan dalam pelaporan keuangan yang telah ditetapkan oleh badan yang memiliki otoritas di pasar modal. Yang pertama adalah ungkapan wajib (mandatory disclosure), yaitu informasi yang harus di ungkapkan oleh emiten yang diatur oleh peraturan pasar modal di suatu Negara. Sedangkan yang kedua adalah ungkapan sukarela (voluntary disclosure), yaitu ungkapan yang dilakukan secara sukarela oleh perusahaan tanpa diharuskan oleh standar yang ada. Pengungkapan CSR termasuk pengungkapan sukarela atau tidak wajib (Rosmasita,2007)

Pengungkapan sosial dalam penelitian ini menggunakan standar GRI, karena Global Reporting Initiative (GRI) merupakan organisasi yang telah mempelopori perkembangan dunia, dan sifatnya internasional. Selain itu GRI paling banyak menggunakan kerangka laporan keberlanjutan dan berkomitmen untuk terus-menerus melakukan perbaikan dan penerapan di seluruh dunia (www.globalreporting.org). Standar GRI yang digunakan untuk penelitian ini mencakup 3 indikator berkelanjutan, yaitu indikator kinerja ekonomi (9 item), lingkungan (30 item) dan sosial (40 item).

Indikator kinerja sosial mencakup empat indikator yang terdiri dari: indikator kinerja tenaga kerja, hak asasi manusia, sosial/kemasyarakatan.

\section{Cost of Equity}

Menurut Amurwani (2006) cost of equity merupakan biaya yang dikeluarkan oleh perusahaan yang memperoleh dana dengan menjual saham biasa atau menggunakan laba yang ditahan untuk investasi. Cost of equity dapat mengalami peningkatan secara internal dengan menahan laba atau secara eksternal dengan menjual atau mengeluarkan saham biasa baru.

Selain itu, definisi menurut Mardiyah (2002) cost of equity merupakan biaya yang dikeluarkan perusahaan untuk membiayai sumber pembiayaan.

Menurut Botosan (1997), biaya ekuitas dipengaruhi oleh tingkat disclosure dan risiko (BETA). Pengungkapan lebih meningkatkan likuiditas saham pasar sehingga mengurangi biaya modal ekuitas baik melalui pengurangan biaya transakasi atau meningkatnya permintaan sekuritas perusahaan. Risiko (BETA) yang ada pada perusahaan rendah maka tingkat pengembalian yang diharapkan investor juga rendah, sehingga COE perusahaan juga rendah.

\section{Pengaruh CSR terhadap Cost of Equity}

Menurut Restuningdiah (2010), pengungkapan CSR merupakan konsep akuntansi yang memperhatikan transparasi pengungkapan sosial atas kegiatan sosial perusahaan, sehingga informasi yang diungkapkan perusahaan tidak hanya informasi keuangan perusahaan, namun juga informasi CSR yang 
termasuk pengungkapan sukarela mengenai dampak sosial dan lingkungan hidup yang diakibatkan oleh kegiatan perusahaan.

Sedangkan konsep cost of equity (COE) menurut Sedek (2009) merupakan biaya yang dibayarkan dalam menarik investor untuk menanamkan uangnya dalam saham perusahaan dan mempertahankan investor tersebut. COE berkaitan dengan risiko investasi saham perusahaan. Apabila risiko perusahaan rendah maka akan membuat investor tertarik menanamkan modalnya di perusahaan tersebut. Sehingga COE penting bagi investor dalam mempertimbangkan keputusan investasi terhadap perusahaan.

Dalam penelitian terdahulu yang dilakukan oleh Amurwani (2006) menunjukan bahwa pengungkapan sukarela tidak berpengaruh tehadap cost of equity capital. Sedangkan penelitian Botosan (1997) disebutkan penelitian Klein dan Bawa (1976), Barry dan Brown (1985), Coles dan Loewenstein (1988), Handa dan Lin (1993), Coles et al.(1995, dan Clarkson et al: (1996) menemukan bahwa makin besar tingkat pengungkapan sukarela akan makin rendah cost of equity melalui penurunan risiko yang tidak dapat didiversifikasi. Hasil penelitian Botosan (1997), Mardiyah (2002), Murni (2003) dan Francis, Nanda dan Olson (2005), berpendapat ada pengaruh negatif tingkat pengungkapan sukarela terhadap cost of equity.

Penelitian Frankel et al. (1995) dan Welker (1995) serta Healy (1999) menunjukkan bukti adanya pengaruh tingkat disclosure terhadap biaya ekuitas. Semakin tinggi tingkat disclosure suatu perusahaan, maka akan mempertinggi nilai perusahaan yang ditunjukkan dengan peningkatan permintaan sekuritas dan peningkatan harga saham yang dimiliki oleh suatu perusahaan yang pada akhirnya berdampak pada pengurangan biaya modal (Juniarti dan Yunita, 2003).

Sedangkan penelitian yang dilakukan oleh Dhaliwal, Zhen Li, dan Tzang (2011) kegiatan CSR berpengaruh negatif terhadap cost of equity perusahaan, karena perusahaan yang bertanggung jawab sosial dapat menikmati penjualan dan kinerja keuangan yang lebih baik karena preferensi konsumen dan investor oleh perusahaan tersebut.

Pengungkapan CSR melalui laporan tahunan dapat memberikan informasi lebih kepada investor. Sehingga tingkat pengungkapan CSR yang tinggi menciptakan kepercayaan investor terhadap perusahaan tersebut dan investor tertarik untuk menginvestasikan modalnya, sehingga COE perusahaan rendah.

Dalam laporan pengungkapan CSR, diungkapkan tentang kegiatan sosial perusahaan. Sebagai contohnya adalah hubungan perusahaan dengan masyarakat. Apabila perusahaan dapat mengurangi pencemaran lingkungan dan dapat memaksimalkan pengelolaan limbah dengan baik maka tanggung jawab sosial perusahaan terhadap sosial masyarakat tinggi sehingga meningkatkan 
citra perusahaan dan mengurangi gangguan masyarakat terhadap operasional perusahaan.

Citra perusahaan yang tinggi akan mengurangi resiko perusahaan dan asimetri informasi. Resiko perusahaan yang rendah dan asimetri informasi yang kecil akan menarik investor untuk menginvestasikan modalnya ke perusahaan, sehingga perusahaan tidak perlu mengeluarkan biaya lagi untuk menarik investor menanamkan modal sehingga menurunkan COE perusahaan.

Sehingga hipotesis penelitian ini adalah:

H1 : Pengungkapan CSR dalam laporan tahunan berpengaruh negatif terhadap cost of equity perusahaan.

\section{METODE PENELITIAN}

\section{Populasi dan Sampel}

Populasi dalam penelitian ini adalah perusahaan-perusahaan manufaktur yang terdaftar di Bursa Efek Indonesia (BEI) tahun 2010. Dalam penelitian ini, pengambilan sampel dilakukan dengan menggunakan metode purposive sampling. Adapun kriteria-kriteria yang digunakan dalam penelitian sampel adalah:

1. Merupakan perusahaan manufaktur yang terdaftar di Bursa Efek Indonesia (BEI) untuk tahun 2010.

2. Merupakan perusahaan manufaktur yang mempublikasikan atau mengupload laporan tahunan tahun 2010 dalam www.idx.co.id atau website perusahaan terkait.

3. Merupakan perusahaan yang data laporan keuangan menggunakan satuan mata uang rupiah sesuai dengan fungsional mata uang Indonesia adalah rupiah. Selain itu dengan tujuan agar konsisten dengan mata uang harga saham perusahaan.

4. Merupakan perusahaan yang IHSG dan harga saham harian diketahui dalam www.financeyahoo.com.

5. Datanya lengkap untuk penelitian, yaitu data untuk CSR, COE, ukuran perusahaan, beta saham, dan nilai kapitalisasi pasar.

\section{Jenis Data dan Sumber Data}

Jenis data yang digunakan dalam penelitian ini adalah data sekunder yang bersumber dari laporan tahunan yang telah diaudit dan dipublikasikan. Datanya adalah pengungkapan CSR, cost of equity, rasio leverage, beta saham yang diambil dari laporan keuangan tahunan (annual report) untuk periode tahun 2010 
yang diperoleh dari Bursa Efek Indonesia melalui website www.idx.co.id atau website perusahaan terkait.

\section{Variabel Independen}

Variabel independen pada penelitian ini adalah pengungkapan tanggung jawab sosial perusahaan. Pengungkapan CSR diukur dengan CSDI (Corporate Social Disclosure Index) dengan menggunakan indikator GRI. Dalam indikator GRI mencakup 3 indikator berkelanjutan, yaitu indikator kinerja ekonomi (9 item), lingkungan (30 item) dan sosial (40 item). Indikator kinerja sosial mencakup empat indikator yang terdiri dari: indikator kinerja tenaga kerja, hak asasi manusia, dan sosial/kemasyarakatan.

Total indikator kinerja mencapai 79 indikator. Pengukuran CSDI mengacu pada penelitian Haniffa dkk. (2005) dalam Sayekti dan Wondabio (2007), yang menggunakan content analysis dalam mengukur variety dari CSDI. Pendekatan ini pada dasarnya menggunakan pendekatan dikotomi yaitu setiap item CSR dalam instrumen penelitian diberi nilai 1 jika diungkapkan, dan nilai 0 jika tidak diungkapkan.

Selanjutnya, skor dari setiap item dijumlahkan untuk memperoleh keseluruhan skor untuk setiap perusahaan. Rumus perhitungan CSDI adalah sebagai berikut:

$$
\text { CSDI }=
$$

\section{Variabel Dependen}

Variabel Dependent pada penelitian ini adalah cost of equity perusahaan. Untuk menghitung cost of equity setiap perusahaan sampel dengan menggunakan metode Capital Asset Pricing Model ( CAPM ), karena pembahasan mengenai pengaruh tingkat pengungkapan CSR terhadap cost of equity juga tidak terlepas dari faktor risiko di dalamnya dan penggunaan pendekatan ini tidak dibatasi oleh pertumbuhan dividen yang konstan sehingga dapat diterapkan pada lingkungan yang lebih luas (Juniarti dan Yunita, 2003).

Langkah-langkah menghitung CAPM adalah sebagai berikut:

1. Menghitung besarnya return bebas risiko yang diproksi dengan tingkat bunga SBI bulan Desember 2010. 
2. Menghitung return pasar yang diperoleh dari indeks harga saham gabungan (IHSG) pada hari t dikurangi IHSG pada hari t-1 dan hasilnya dibagi dengan IHSG hari t-1 sesuai bulan Desember 2010.

3. Menentukan besamya risiko sistematis $(\beta)$ dari saham yang dianalisis. Dihitung dengan regresi linear sederhana antara return saham dengan return pasar dengan program SPSS. Menggunakan data saham perusahaan tahun 2010.

4. Menentukan besarnya tingkat pengembalian yang diisyaratkan (required return) dari saham yang bersangkutan.

Perhitungan metode CAPM, yaitu:

$$
\mathrm{COE}_{\mathrm{i}, \mathrm{t}}=\mathrm{R}_{\mathrm{ft}}+\beta \mathrm{i}\left(\mathrm{R}_{\mathrm{Mt}}-\mathrm{R}_{\mathrm{ft}}\right)
$$

Dimana:

$\mathrm{R}_{\mathrm{ft}}=$ return bebas resiko yang diproksi dengan tingkat bunga SBI bulanan

$\mathrm{R}_{\mathrm{Mt}}=$ return pasar yang diperoleh dari indeks harga saham gabungan (IHSG) pada hari t dikurangi IHSG pada hari t-1 dan hasilnya dibagi dengan IHSG hari t-1.

$\beta=$ beta saham

$\mathrm{i}=$ perusahaan

\section{Variabel Kontrol}

Ukuran perusahaan

Ukuran perusahaan dalam penelitian ini menggunakan kapitalisasi pasar, yaitu perkalian antara harga saham per 31 Desember dengan jumlah saham yang beredar. Diamond dan Verrecchia (1991) dalam Murni (2003) menyatakan bahwa perusahaan yang lebih besar dengan total resiko yang ditanggung oleh investor lebih besar, akan mendapatkan keuntungan per saham yang terbesar (dalam hal ini peningkatan nilai saham) sebagai hasil dari peningkatan ungkapan.

Hasil penelitian yang dilakukan Suripto (1999), Gunawan (2000), dan Komalasari (2000) dalam Sasongko dan Supatmi (2008) menunjukan bahwa ukuran perusahaan terbukti merupakan variabel yang cukup konsisten mempengaruhi hubungan pengungkapan CSR terhadap cost of equity (COE) perusahaan.

Financial leverage

Financial leverage dalam penelitian ini dihitung menggunakan debt to asset ratio, ratio ini merupakan alat untuk mengukur seberapa besar perusahaan 
tergantung pada kreditur dalam membiayai asset perusahaan. Perusahaan yang mempunyai tingkat leverage tinggi berarti sangat bergantung pada pinjaman luar untuk membiayai assetnya. Sedangkan perusahaan yang mempunyai tingkat leverage lebih rendah lebih banyak membiayai assetnya dengan modal sendiri. Hasil penelitian yang dilakukan oleh Arti (2009) menunjukan bahwa financial leverage bersifat positif terhadap cost of equity perusahaan. Debt to Asset Ratio dihitung dengan rumus dari Kasmir (2009):

$$
\text { DAR }=\frac{\text { Total Hutang }}{\text { Total ASet }} \times 100 \%
$$

\section{Metode Analisis Data}

1. Uji Asumsi Klasik

Pengujian asumsi klasik ini bertujuan untuk mengetahui dan menguji kelayakan atas model regresi yang digunakan dalam penelitian ini. Pengujian ini juga dimaksudkan untuk memastikan bahwa di dalam model regresi yang digunakan tidak terdapat multikolonieritas dan heteroskedastisitas serta untuk memastikan bahwa data yang dihasilkan berdistribusi normal (Ghozali, 2006).

a. Uji Normalitas

Uji normalitas bertujuan untuk melihat apakah data yang dianalisis memiliki nilai residual di sekitar nol. Model regresi yang baik hendaknya berdistribusi normal atau mendekati normal. Salah satu cara dalam pengujian ini dilakukan dengan Uji Kolmogoruov-Smirnov.

b. Multikolonieritas

Yaitu indikasi adanya hubungan linier diantara variabel independen. Pendeteksiannya dilakukan dengan tolerance value dan VIF, jika tolerance value $>0.10$ dan VIF $<10$, maka tidak terjadi multikolinieritas.

c. Heteroskedastisitas

Untuk mendeteksi gejala heteroskedastis dalam persamaan regresi. Uji heteroskedastisitas dilakukan dengan menggunakan Glesjer Test, jika nilai signifikansinya $>5 \%$, maka dapat disimpulkan tidak terdapat heteroskedastisitas.

2. Metode Analisis Data

Penelitian ini menggunakan regresi berganda untuk menguji hubungan antara varibel independen dan variabel dependen. 
Persamaan yang digunakan untuk menguji hipotesis adalah sebagai berikut:

$C O E=\alpha+\beta_{1} C S R+\beta_{2 s} \log S I Z E+\beta_{3} L E V+e$

Keterangan:

$\mathrm{COE}=$ Cost of Equity

$\alpha \quad=$ konstanta

$\beta 1-\beta 3=$ koefisien regresi

CSR = tingkat pengungkapan CSR

SIZE = ukuran perusahaan yag sudah di LOG

$\mathrm{LEV}=$ rasio leverage

$\mathrm{E}=$ Error

\section{HASIL DAN PEMBAHASAN}

Penelitian ini menggunakan data sekunder yang diperoleh dari laporan tahunan yang dipublikasikan di internet melalui situs Bursa Efek Indonesia (www. idx.co.id). Berdasarkan kriteria yang telah ditentukan sebelumnya, diperoleh sampel penelitian dengan rincian sebagai berikut:

Tabel 1. Sampel Penilitian Tahun 2010

\begin{tabular}{lc}
\multicolumn{1}{c}{ Kriteria Sample } & $\begin{array}{c}\text { Jumlah } \\
\text { Perusahaan }\end{array}$ \\
\hline $\begin{array}{l}\text { Perusahaan manufaktur yang terdaftar di BEl untuk tahun 2010 } \\
\begin{array}{l}\text { Perusahaan manufaktur yang belum mempublikasikan laporan } \\
\text { tahunan tahun 2010 }\end{array}\end{array}$ & $(26)$ \\
$\begin{array}{l}\text { Perusahaan yang data laporan keuangan yang tidak dalam satuan } \\
\text { mata uang rupiah }\end{array}$ & $(37)$ \\
$\begin{array}{l}\text { Perusahaan yang IHSG dan harga saham harian tidak diketahui } \\
\text { Data outlier }\end{array}$ & $(6)$ \\
\hline Jumlah sampel & $(5)$ \\
\hline
\end{tabular}

Sumber :www.idx.co.id

\section{Statistik Deskriptif}

Analisis statistik deskriptif digunakan untuk memberikan gambaran atau deskripsi suatu data, variabel-variabel penelitian yang digunakan dalam penelitian ini dilihat dari nilai rata-rata (mean), maksimum, minimum. 
Tabel 2. Statistik Deskriptif Variabel Penelitian

\begin{tabular}{lccc}
\hline & Minimum & Maksimum & Mean \\
\hline CSR & 0.04 & 0.44 & 0.24 \\
COE & 2.44 & 8.89 & 5.89 \\
SIZE & 9.43 & 14.08 & 11.96 \\
LEV & 0.04 & 2.42 & 0.58 \\
\hline
\end{tabular}

Sumber: Output SPSS 16.0 tahun 2012

Tabel 3. Statistik Deskriptif Indikator pengungkapan tanggungjawab sosial (CSR) berdasarkan index GRI

\begin{tabular}{lccc}
\hline \multicolumn{1}{c}{ Indikator } & $\begin{array}{c}\text { Minimum } \\
(\%)\end{array}$ & $\begin{array}{c}\text { Maksimum } \\
(\%)\end{array}$ & $\begin{array}{c}\text { Mean } \\
(\%)\end{array}$ \\
\hline EC (ekonomi) & 22.22 & 77.78 & 53.40 \\
EN (lingkungan) & 0.00 & 50.00 & 17.44 \\
LA (tenaga kerja) & 7.14 & 64.29 & 26.15 \\
HR (hak asasi manusia) & 0.00 & 55.56 & 7.65 \\
SO (masyarakat) & 0.00 & 50.00 & 12.99 \\
PR (tanggung jawab produk) & 0.00 & 100.00 & 29.30 \\
\hline
\end{tabular}

Sumber: Output SPSS 16.0 tahun 2012

Berdasarkan hasil penelitian diperoleh 77 sampel. Dari 77 sampel yang digunakan ditemukan adanya outlier atau disebut juga sebagai data yang terlalu menyimpang dan memiliki nilai terlalu besar dari data yang lainnya. Setelah dilakukan pengeluaran data yang dianggap outlier diperoleh 72 sampel. Data perusahaan yang dianggap outlier antara lain AKKU, LION, MASA, SIAP, VOKS karena menurut Hair (1998) untuk kasus sampel kecil (kurang dari 80 perusahaan) maka standar skor dengan nilai $\pm 2,5$ dinyatakan outlier.

Berdasarkan hasil SPPS menunjukkan bahwa Indeks pengungkapan tanggung jawab sosial perusahaan manufaktur (CSR) memiliki nilai terendah (minimum) 0.04 yaitu PT. Primarindo Asia Infrastructure Tbk. dan nilai tertinggi (maksimum) sebesar 0,44 yaitu oleh PT. Unilever Tbk. Sedangkan nilai rata rata (mean) pengungkapan kegiatan sosial perusahaan (CSR) sebesar 0,24. Ini menunjukan proporsi pengungkapan CSR lebih besar dari penelitian sebelumnya yang dilakukan Fahrizqi (2010) yang nilai rata-rata pengungkapan CSR sebesar 0,12 .

Nilai ini menunjukkan bahwa perusahaan manufaktur yang go public ratarata di bawah 0,5 . Hal tersebut menunjukkan bahwa penungkapan tanggung 
jawab sosial (CSR) pada perusahaan manufaktur yang go public di Indonesia tahun 2010 masih tergolong rendah.

Hasil SPSS variabel ukuran perusahaan (SIZE) menunjukan bahwa ukuran perusahaan memiliki nilai terendah (minimum) adalah 9,43 yaitu PT. Citra Marga Nusaphala Persada dan nilai tertinggi (maximum) adalah 14.08 yaitu oleh PT. Unilever Tbk. Sedangkan nilai rata-rata (mean) ukuran perusahaan sebesar 11.96 .

Hasil SPSS variabel leverage (LEV) menunjukan bahwa leverage memiliki nilai rendah (minimum) adalah $4 \%$ yaitu PT. Intan Wijaya Internasional, nilai tertinggi (maximum) adalah $24,2 \%$ yaitu PT. Prima Alloy Stell. Sedangkan nilai rata-rata (mean) leverage sebesar 0,58 , yang menunjukan bahwa $58 \%$ asset perusahaan dibiayai oleh hutang sedangkan $42 \%$ dibiayai oleh ekuitas.

Hasil SPSS variabel cost of equity (COE) menunjukan bahwa cost of equity memiliki nilai rendah (minimum) adalah $2,44 \%$ yaitu PT. Resource Alam Indonesia dan nilai tertinggi (maximum) adalah $8,89 \%$ yaitu PT. Merck sedangkan nilai ratarata (mean) cost of equity sebesar $6,01 \%$. Hal tersebut menunjukan bahwa ratarata biaya modal yang dikeluarkan perusahaan untuk pengungkapan informasi yang dianggap sebagai investasi jangka panjang perusahaan sebesar 6,01\%

Berdasarkan Pedoman GRI terdapat 6 indikator yang digunakan untuk mengukur pengungkapan CSR yaitu kinerja ekonomi, lingkungan, sosial, hak asasi manusia, kemasyarakatan dan tanggung jawab produk. Pada tabel 3 dapat di lihat bahwa di antara ke 6 indikator tersebut yang memiliki rata-rata tertinggi adalah kinerja ekonomi dengan nilai rata-rata $53,40 \%$. Hal tersebut dimungkinkan karena indikator kinerja ekonomi memiliki informasi yang menarik karena berhubungan dengan laba organisasi dan pengaruhnya terhadap stakeholder perusahaan dibandingkan dengan indikator lainnya.

\section{Uji Asumsi Klasik}

\section{a. Hasil uji normalitas}

Uji normalitas bertujuan untuk menguji apakah dalam model regresi, variabel pengganggu atau residual memiliki distribusi normal. Pengujian normalitas pada penelitian ini dilakukan berdasarkan uji KolmogorovSmirnov. Hasil pengujian ini menunjukkan bahwa tingkat signifikan berada di atas $5 \%$, yaitu $5.8 \%$. Dengan nilai Kolmogorov-Smirnov 1.331. Dengan demikian dapat disimpulkan bahwa nilai seluruh variabel memiliki distribusi normal. 


\section{b. Hasil uji multikolinearitas}

Uji multikolineritas ini dimaksudkan untuk mengidentifikasi ada tidaknya hubungan antara variabel independen dan kontrol dalam regresi. Pengujian terhadap multikolinieritas dilakukan dengan uji Variance Inflation Factor (VIF). Uji multikolinieritas dapat terpenuhi jika nilai VIF dalam outpus SPSS di bawah 10 dan nilai tolerance di atas 0,1 . Dan VIF pada variabel penelitian ini antara 1.04 sampai dengan 1.15 dan nilai tolerance 0.87 sampai dengan 0.96 . Dari nilai yang dihasilkan berarti data bebas dari multikolinieritas karena VIF di bawah 10 dan nilai tolarance di atas 0,1 .

c. Hasil uji heteroskedastisitas

Uji Heteroskedaktisitas adalah adanya varians yang berbeda yang dapat membiaskan hasil yang telah dihitung, serta menimbulkan konsekuensi adanya model yang akan menaksir terlalu rendah varians yang sesungguhnya. Penelitian ini dilakukan dengan uji Glesjer. Metode ini melihat nilai signifikansi dan apabila nilai signifikansi di atas 0.05 dengan demikian bahwa tidak terjadi heteroskedaktisitas. Nilai signifikansi pada penelitian ini antara 0.071 sampai dengan 0.946 sehingga dapat disimpulkan penelitian ini tidak terjadi heteroskedaktisitas.

\section{Uji Hipotesis}

Hasil perhitungan analisis regresi guna menguji hipotesis yang diajukan dapat dilihat pada tabel 4 sebagai berikut:

Tabel 4. Hasil Uji Regresi

\begin{tabular}{ccc}
\hline Variabel & B & Sign. \\
\hline CSR & -1.16 & 0.36 \\
LEV & -0.00 & 0.49 \\
SIZE & 0.43 & 0.09 \\
\hline
\end{tabular}

Sig $F=0.56 R^{2}=0.023$

Dari hasil uji statistika didapatkan $\mathrm{R}^{2}$ sebesar $2,3 \%$ yang mengindi-kasikan variabel dependen cost of equity sebesar $2,3 \%$ dijelaskan oleh variabel independen yaitu corporate social responsibility, ukuran perusahaan, dan financial leverage (variabel kontrol) dan $97,7 \%$ cost of equity dipengaruhi oleh variabel lainnya.

Berdasarkan uji hipotesis yang diajukan dalam penelitian ini bisa dilihat bahwa variabel pengungkapan CSR memiliki tingkat signifikansi sebesar 0.36. Nilai ini lebih dari 0.05 , oleh karena itu bisa dikatakan bahwa pengungkapan CSR tidak berpengaruh signifikan terhadap cost of equity (COE) perusahaan. Maka dapat disimpulkan $\mathrm{H} 1$ ditolak. 
Amurwani (2006) menemukan luas pengungkapan sukarela tidak berpengaruh signifikan terhadap $\mathrm{COE}$. Hal ini disebabkan luas pengungkapan yang disampaikan masih belum memadai sehingga tidak memperoleh dampak menurunnya COE. Pengungkapan CSR termasuk pengungkapan sukarela sehingga pengungkapan CSR tidak berpegaruh terhadap COE.

Pengungkapan CSR yang rendah tidak mempengaruhi menurunnya COE perusahaan, walaupun pengungkapan CSR perusahaan rendah, investor tetap menginvestasikan sahamnya ke perusahaan tersebut. Bukti dari hasil penelitian ditunjukan oleh PT. Resource Alam Indonesia yang mempunyai indeks CSR sebesar $10 \%$ dengan nilai COE sebesar $24.4 \%$. Hal ini dimungkinkan ada faktorfaktor lain yang bernilai tinggi yang dilihat dari sisi investor selain pengungkapan CSR.

Agustini (2011) menemukan bahwa investor individual tertarik terhadap informasi sosial yang dilaporkan dalam laporan keuangan. Informasi tersebut berupa keamanan dan kualitas produk serta aktivitas lingkungan. Selain itu mereka menginginkan informasi mengenai etika, hubungan dengan karyawan dan masyarakat. Hasil rata-rata pengungkapan CSR pada penelitian ini sebesar $24 \%$. Hal tersebut menyimpulkan bahwa pengungkapan CSR pada perusahaan manufaktur di Indonesia masih rendah sehingga tidak berpengaruh signifikan terhadap COE perusahaan.

Selain itu kemungkinan bahwa COE perusahaan tidak hanya tergantung dengan pengungkapan CSR tetapi lebih dimungkinkan karena adanya pegungkapan lain seperti informasi pasar modal, informasi laporan keuangan atau informasi pembayaran deviden.

Hasil penelitian ini tidak sesuai dengan penelitian Dhaliwal, Zhen Li, dan Tzang (2011), Gregory dkk. (2010), Sadok El Ghoul dkk. (2010) yang menemukan bahwa makin tinggi pengungkapan CSR maka makin rendah COE perusahaan. Namun penelitian ini mendukung penelitian Gulo (2000), Amurwani (2006), yang menemukan bahwa tidak ada pengaruh signifikan pengungkapan sukarela terhadap COE perusahaan dan penelitian Heru (2008), yang menemukan bahwa pengungkapan CSR tidak berpengaruh terhadap COE perusahaan.

Penelitian ini juga menemukan bahwa variabel kontrol ukuran perusahaan mempengaruhi COE perusahaan pada tingkat signifikansi 9\%. Ukuran perusahaan berpengaruh signifikan terhadap COE perusahaan karena semakin besar ukuran perusahaan maka biaya yang dikeluarkan untuk pengungkapan CSR semakin besar, maka akan berpengaruh juga terhadap cost of equity perusahaan. Hasil penelitian ini konsisten dengan hasil penelitian yang dilakukan Suripto (1999), Gunawan (2000), dan Komalasari (2000). 
Financial leverage tidak mempengaruhi COE perusahaan. Dalam penelitian Jauhari (2002), Cornell dan Shapiro (1987) berpendapat bahwa manajer dari suatu perusahaan dapat memberikan signal mengenai kemampuan mereka untuk melakukan pembayaran pada klaim implisit mereka dengan membayar deviden yang lebih tinggi.

Leverage tinggi maka resiko perusahaan tinggi, tetapi investor tetap menginvestasikan sahamnya ke perusahaan dimungkinkan prospek perusahaan kedepan lebih maju dilihat dari laba perusahaan tersebut sehingga COE perusahaan rendah contohnya adalah PT. Prima Alloy Stell yang mempunyai tingkat leverage $24,2 \%$ tetapi COE perusahaan rendah dibawah rata-rata sebesar $52,4 \%$. Hal ini dimungkinkan sudah terjadi hubungan yang baik antara perusahaan dengan kelompok investor yang mengakibatkan investor tidak terlalu memperhatikan rasio leverege perusahaan tersebut.

\section{PENUTUP}

\section{Kesimpulan}

Penelitian ini dimaksudkan untuk mengetahui pengaruh pengungkapan corporate social responbility (CSR) terhadap cost of equity (COE) perusahaan. Berdasarkan hasil analisis yang dilakukan dengan menggunakan 77 perusahaan manufaktur yang terdaftar di BEJ periode 2010 dapat diambil kesimpulan sebagai berikut:

1. Hasil pengujian hipotesis pertama menunjukkan bahwa pengungkapan CSR tidak berpengaruh signifikan terhadap cost of equity perusahaan. Hal ini sesuai dengan penelitian Gulo (2000), Amurwani (2006), Heru (2008).

2. Hasil pengujian variabel kontrol ukuran perusahan berpengaruh signifikan terhadap cost of equity perusahaan. Hal ini sesuai dengan penelitian Suripto (1999), Gunawan (2000), dan Komalasari (2000).

3. Hasil pengujian variabel kontrol financial leverage tidak berpengaruh signifikan terhadap cost of equity perusahaan. Hal ini sesuai dengan penelitian Putri (2010).

\section{Keterbatasan Penelitian}

Penelitian ini memiliki keterbatasan-keterbatasan yang sekaligus dapat merupakan arah bagi penelitian yang akan datang antara lain :

1. Terdapat unsur subjektivitas dalam memberi penilaian pengungkapan CSR. Hal ini dikarenakan perbedaan pemahaman konsep indikator, sehingga nilai pengungkapan CSR dalam kategori yang sama berbeda untuk setiap peneliti. 
2. Penelitian ini hanya mengidentifikasi 3 faktor yang mempengaruhi $\mathrm{COE}$ dalam laporan tahunan perusahaan karena keterbatasan waktu penelitian.

3. Penelitian ini hanya mengambil jangka waktu setahun yaitu tahun 2010 sehingga data yang diambil ada kemungkinan kurang mencerminkan kondisi perusahaan dalam jangka panjang.

\section{Implikasi}

- Bagi Investor

Dalam membuat keputusan menanamkan investasi ke perusahaan, investor sebaiknya tidak hanya melihat faktor pengungkapan Corporate Social and Responbility (CSR) terhadap masyarakat lingkungan saja, karena ada beberapa faktor lainnya yang dapat mempengaruhi cost of equity perusahaan antara lain informasi pasar modal, informasi laporan keuangan atau informasi pembayaran deviden.

- Bagi Perusahaan

Dari hasil penelitian, perusahaan disarankan untuk meningkatkan nilai kapitalisasi pasar (ukuran perusahaan), karena investor cenderung tertarik kepada perusahaan besar. Selain itu makin besar nilai kapitalisasi pasar maka semakin besar pula perusahaan dikenal masyarakat (Sudarmadji dan Sularto, 2007).

\section{Saran}

Berdasarkan beberapa keterbatasan penelitian yang telah diungkapkan, maka diberikan saran untuk penelitian selanjutnya yaitu penelitian selanjutnya lebih memperpanjang tahun penelitian sehingga memperoleh sample yang lebih banyak lagi. 


\section{DAFTAR PUSTAKA}

Agustini, Yuli. 2011. "Pengaruh Daya Informasi Akuntansi Pada Hubungan Pengungkapan Corporate Social Responbility Dengan Cost Of Equity Capital". Thesis Program S2, Universitas Udayana, Denpasar.

Amurwani, Aniek. 2006. "Pengaruh Luas Pengungkapan Sukarela dan Asimetri Informasi Terhadap Cost of Equity Capital". Skripsi Program S1, Universitas Islam Indonesia, Jogjakarta.

Bassen, A., H.-M. Hölz, and J. Schlange, 2006, The Influence of Corporate Responsibility on the Cost Of Capital: An Empirical Analysis, Hamburg: Schlange \& Co, Universität Hamburg, Deutsche Bank.

Botosan, C., 1997, "Disclosure Level and the Cost of Equity Capital." The Accounting Review 72,323-349.

Darwin, Ali. 2004. "CSR; Standards dan Reporting". Makalah disampaikan pada Seminar Nasional CSR sebagai Kewajiban Asasi Perusahaan; Telaah Pemerintah, Pengusaha, dan Dewan Standar Akuntansi, tanggal 18 juni 2008 di Unika Soegijapranata Semarang.

Dhaliwal, D. S., Zhen, Li., Tsang, Albert., George, Yong. 2011. "Voluntary Nonfinancial Disclosure and the Cost of Equity Capital:The Initiation of Corporate Social Responsibility Reporting". The Accounting Review, Vol. 86, No. 12011 , pp. 59-100.

El, S. G., Guedhami, Omrane., C, Chuck. Y. K., Misra, Dev. 2010. "Does Corporate Social Responbility Affect the Cost of Capital?". www. ssrn.com.

Francis, J., R. Lafond, P. M. Olsson, and K. Schipper, 2005, The Market Pricing of Accruals Quality, Journal of Accounting and Economics 39, 295327.

Ghozali, Imam. 2006. Analisis Multivariate dengan Program SPSS. Edisi Ke 4. Badan Penerbit Universitas Diponegoro : Semarang

Gulo, Y., 2000. "Analisis Efek Luas Pengungkapan Sukarela dalam Laporan Tahunan Terhadap Cost of Equity Capital Perusahaan". Jurnal Bisnis dan Akuntansi, Vol.2 No.1, April, hal 45-62.

.Gunawan, Y. 2000, "Analisis Pengunfkapan Informasi Laporan Tahunan Pada Perusahaan Terdaftar di Bursa Efek Jakarta", Simposium Nasional Akuntansi Nasional III, Jakarta, hal. 78-98. 
Gregory, Alan., Whittaker, Julie., and Yan, Xiaojuan. 2010. "Stock Market Valuation of Corporate Social Responsibility Indicators". www.ssrn. com.

Heru, Fajar Pratomo. 2008. "Pengaruh Tingkat Disclosure, Ukuran Perusahaan, dan Tingkat Risiko Terhadap Cost Of Equity Capital (Studi pada perusahaan food and Beverage yang listing di BEJ periode 20052006)." Skripsi Program S1, Universitas Negeri Malang, Malang.

Komalasari, P.T. 2000, "Asimetri Informasi dan Cost Of Equity Capital", Simposium Nasional Akuntansi III, Jakarta, hal. 907-930.

Mardiyah, Aida Ainul. 2002,"Pengaruh Informasi Asimetri dan Disclosure terhadap Cost of Capital “, Jurnal Riset Akuntansi Indonesia, Vol.5,No.2, Mei, Hal.229-256

Murni, 2003, "Pengaruh Luas Ungkapan Sukarela dan Asimetri Informasi terhadap Cost of Equity Capital pada Perusahaan Publik di Indonesia", Simposium Nasional Akuntansi VI.

Putri, Arti Pratiwi, 2009."Pengaruh Rasio Leverage Terhadap Biaya Modal (Studi Kasus pada PT.TELKOM Tbk Periode Tahun 2005-2009)". Universitas Komputer Indonesia.

Restuningdiah, Nurika. 2010. "Mekanisme GCG dan Pengungkapan Tanggung Jawab Sosial Terhadap Koefisien Respon Laba". Jurnal Keuangan dan Perbankan. Volume 14 Nomor 3.September: 377-390

Rosmasita, Hardhina. 2007," Faktor - Faktor yang Mempengaruhi Pengungkapan Sosial ( Social Disclosure) dalam Laporan Keuangan Tahunan Perusahaan Manufaktur di Bursa Efek Jakarta". Skripsi Program S1, Universitas Islam Indonesia, Yogyakarta.

Ross et. al. 1998. "Fundamentals of Corporate Finance (fourth edition)". Singapore: McGraw Hill-Irwin (International Edition).

Sari, N.M.P., dan Kholisoh, L. 2009. "Pengaruh Karakteristik Perusahaan terhadap CSR Pada Perusahaan Manufaktur." Universitas Gunadharma: Fakultas Ekonomi Akuntansi.

Sasongko, Wenang Yudha dan Supatmi. 2008, "Dampak Tingkat Pengungkapan Corporate Social Responbility Terhadap Biaya Modal Ekuitas". Simposium Nasional. Hasil Riset Ekonomika dan Bisni Asosiasi Perguruan Tinggi Katolik (APTIK) 2008. 
Sayekti, Yosefa dan Ludovicus Sensi Wondabio. 2007, "Pengaruh CSR Disclosure terhadap Earning Response Coefficient (Suatu Studi Empiris pada Perusahaan yang Terdaftar di Bursa Efek Jakarta)." Makalah disampaikan pada Simposium Nasional Akuntansi IX, Makassar, 26-28 Juli 2007.

Sembiring, E. R. 2005. "Karakteristik Perusahaan dan Pengungkapan Tanggung Jawab Sosial : Studi Empiris pada Perusahaan yang Tercatat di Bursa Efek Jakarta". Makalah Disampaikan dalam Simposium Nasional Akuntansi VIII. Solo, 15-16 September.

Suripto, B. 1999, "Pengaruh Karakteristik Perusahaan Terhadap Luas Pengungkapan Sukarela dalam Laporan Tahunan". Simposium Nasional Akuntansi. Malang.

Utama, Sidharta. 2007, "Evaluasi Infrastruktur Pendukung Pelaporan Tanggung Jawab Sosial dan Lingkungan di Indonesia". www.ui.edu. Diakses tanggal 19 Juni 2008.

Utomo, M. 2000. "Praktek Pengungkapan Sosial Pada Laporan Tahunan Perusahaan di Indonesia (Studi Perbandingan Antara Perusahaan High Profile dan Low Profile)". Simposium Nasional Akuntansi IV. IAI

Yunita, Frency dan Juniarti. 2003, "Pengaruh Tingkat Disclosure Terhadap Biaya Ekuitas". Jurnal Akuntansi dan Keuangan, Vol.5,No.2,November, Hal 150-168

Yusrina. 2010. "Pengaruh Leverage dan Profitabilitas Perusahaan Terhadap Corporate Sosial Responbility Disclosure pada Perusahaan Manufaktur yang Go Public di Indonesia". Skripsi Program S1, Universitas Andalas, Padang. 


\section{Lampiran : Corporate Social Responsibility Disclosure berdasarkan GRI}

\section{Economic Performance Indicators}

\begin{tabular}{|c|c|}
\hline \multicolumn{2}{|c|}{ 1. Aspect: Economic Performance } \\
\hline $\mathrm{EC} 1$ & $\begin{array}{l}\text { Direct economic value generated and distributed, including revenues, } \\
\text { operating costs, employee compensation, donations and other } \\
\text { community investments, retained earnings, and payments to capital } \\
\text { providers and governments. }\end{array}$ \\
\hline $\mathrm{EC} 2$ & $\begin{array}{l}\text { Financial implications and other risks and opportunities for the } \\
\text { organization's activities due to climate change. }\end{array}$ \\
\hline EC3 & Coverage of the organization's defined benefit plan obligations. \\
\hline EC4 & Significant financial assistance received from government. \\
\hline \multicolumn{2}{|c|}{ 2. Aspect: Market Presence } \\
\hline EC5 & $\begin{array}{l}\text { Range of ratios of standard entry level wage compared to local } \\
\text { minimum wage at significant locations of operation. }\end{array}$ \\
\hline EC6 & $\begin{array}{l}\text { Policy, practices, and proportion of spending on locally-based } \\
\text { suppliers at significant locations of operation. }\end{array}$ \\
\hline EC7 & $\begin{array}{l}\text { Procedures for local hiring and proportion of senior management } \\
\text { hired from the local community at significant locations of operation }\end{array}$ \\
\hline \multicolumn{2}{|c|}{ 3. Aspect: Indirect Economic Impacts } \\
\hline EC8 & $\begin{array}{l}\text { Development and impact of infrastructure investments and services } \\
\text { provided primarily for public benefit through commercial, in-kind, } \\
\text { or pro bono engagement. }\end{array}$ \\
\hline EC9 & $\begin{array}{l}\text { Understanding and describing significant indirect economic } \\
\text { impacts, including the extent of impacts. }\end{array}$ \\
\hline
\end{tabular}

\section{Environmental Performance Indicators}

\begin{tabular}{ll}
\hline 1. Aspect: Materials \\
\hline EN1 & Materials used by weight or volume. \\
EN2 & Percentage of materials used that are recycled input materials. \\
\hline 2. Aspect: & Energy \\
\hline EN3 & Direct energy consumption by primary energy source. \\
EN4 & Indirect energy consumption by primary source. \\
EN5 & Energy saved due to conservation and efficiency improvements. \\
EN6 & $\begin{array}{l}\text { Initiative to provide energy-efficient or renewable energy-based } \\
\text { products and services, and reductions in energy requirements }\end{array}$ \\
& $\begin{array}{l}\text { as a result of these initiatives. } \\
\text { EN7 }\end{array}$ \\
& Initiatives to reduce indirect energy consumption and reductions \\
\hline 3. Aspect: Water \\
\hline EN8 & Total water withdrawal by source. \\
EN9 & Water sources significantly affected by withdrawal of water. \\
EN10 & Percentage and total volume of water recycled and reused. \\
\hline
\end{tabular}




\section{Aspect: Biodiversity}

\begin{tabular}{|c|c|}
\hline EN11 & $\begin{array}{l}\text { Location and size of land owned, leased, managed in, or adjacent to, } \\
\text { protected areas and areas of high biodiversity value outside protected } \\
\text { areas. }\end{array}$ \\
\hline EN12 & $\begin{array}{l}\text { Description of significant impacts of activities, products, and } \\
\text { services on biodiversity in protected areas and areas of high } \\
\text { biodiversity value outside protected areas. }\end{array}$ \\
\hline EN13 & Habitats protected or restored. \\
\hline EN14 & $\begin{array}{l}\text { Strategies, current actions, and future plans for managing impact on } \\
\text { biodiversity. }\end{array}$ \\
\hline EN15 & $\begin{array}{l}\text { Number of IUCN Red List species and national conservation list } \\
\text { species with habitats in areas affected by operations, by level of } \\
\text { extinction risk. }\end{array}$ \\
\hline \multicolumn{2}{|c|}{ 5. Aspect: Emissions, Effluents, and Waste } \\
\hline EN16 & Total direct and indirect greenhouse gas emissions by weight. \\
\hline EN17 & Other relevant indirect greenhouse gas emissions by weight. \\
\hline EN18 & Initiatives to reduce greenhouse gas emissions and reductions achieved \\
\hline EN19 & Emissions of ozone-depleting substances by weight. \\
\hline EN20 & NOx, SOx, and other significant air emissions by type and weight. \\
\hline EN21 & Total water discharge by quality and destination. \\
\hline EN22 & Total weight of waste by type and disposal method. \\
\hline EN23 & Total number and volume of significant spills. \\
\hline EN24 & $\begin{array}{l}\text { Weight of transported, imported, exported, or treated waste deemed } \\
\text { hazardous under the term of the Basel Convention Annex I,II,III,and IV } \\
\text { and percentage of transported waste shipped internationally. }\end{array}$ \\
\hline EN25 & $\begin{array}{l}\text { Identity, size, protected status, and biodiversity value of water } \\
\text { bodies and related habitats significantly affected by the reporting } \\
\text { organization's discharge of water and runoff. }\end{array}$ \\
\hline
\end{tabular}

\begin{tabular}{ll}
\hline 6. Aspect: Products and Services \\
\hline EN26 & $\begin{array}{l}\text { Initiatives to mitigate environmental impacts of products and services, } \\
\text { and extent of impact mitigation. }\end{array}$ \\
EN27 & $\begin{array}{l}\text { Percentage of products sold and their packaging materials that are } \\
\text { reclaimed by category. }\end{array}$ \\
\hline
\end{tabular}

\section{Aspect: Compliance}

EN28 Monetary value of significant fines and total number of non monetary sanctions for non-compliance with environmental law and regulations.

\begin{tabular}{ll}
\hline 8. Aspect: Transport \\
\hline EN29 & $\begin{array}{l}\text { Significant environmental impacts of transporting products and other } \\
\text { goods and materials used for the organization's operations, and } \\
\text { transporting members of the workforce. }\end{array}$ \\
\hline 9. Aspect: Overall \\
\hline EN30 & Total environmental protection expenditures and investments by type. \\
\hline
\end{tabular}


Labor Practices and Decent Work Perfomance Indicators

\begin{tabular}{|c|c|}
\hline \multicolumn{2}{|c|}{ 1. Aspect: Employment } \\
\hline LA1 & Total workforce by employment type, employment contract,and region. \\
\hline LA2 & $\begin{array}{l}\text { Total number and rate of employee turnover by age group, gender,and } \\
\text { region. }\end{array}$ \\
\hline LA3 & $\begin{array}{l}\text { Benefits provided to full-time employees that are not provided to } \\
\text { temporary or part-time employees, by major operations. }\end{array}$ \\
\hline \multicolumn{2}{|c|}{ 2. Aspect: Labor/Management Relations } \\
\hline LA4 & Percentage of employees covered by collective bargaining agreements. \\
\hline LA5 & $\begin{array}{l}\text { Minimum notice period(s) regarding significant operational changes, } \\
\text { including whether it is specified in collective agreements. }\end{array}$ \\
\hline \multicolumn{2}{|c|}{ 3. Aspect: Occupational Health and Safety } \\
\hline LA6 & $\begin{array}{l}\text { Percentage of total workforce represented in formal joint management } \\
\text { worker health and safety committees that help monitor and advise } \\
\text { on occupational health and safety programs. }\end{array}$ \\
\hline LA7 & $\begin{array}{l}\text { Rates of injury, occupational diseases, lost days, and absenteeism, and } \\
\text { total number of work-related fatalities by region. }\end{array}$ \\
\hline LA8 & $\begin{array}{l}\text { Education, training, counseling, prevention, and risk-control program in } \\
\text { place to assist workforce members, their families, or community members } \\
\text { regarding serious diseases. }\end{array}$ \\
\hline LA9 & Health and safety topics covered in formal agreements with trade unions. \\
\hline \multicolumn{2}{|c|}{ 4. Aspect: Training and Education } \\
\hline LA10 & Average hours of training per year per employee by employee category. \\
\hline LA11 & $\begin{array}{l}\text { Programs for skills management and lifelong learning that support the } \\
\text { continued employability of employees and assist them in managing career } \\
\text { endings. }\end{array}$ \\
\hline LA12 & $\begin{array}{l}\text { Percentage of employees receiving regular performance and career } \\
\text { development reviews. }\end{array}$ \\
\hline \multicolumn{2}{|c|}{ 5. Aspect: Diversity and Equal Opportunity } \\
\hline LA13 & $\begin{array}{l}\text { Composition of governance bodies and breakdown of employees per } \\
\text { category according to gender, age group, minority group membership, and } \\
\text { other indicators of diversity. }\end{array}$ \\
\hline LA14 & Ratio of basic salary of men to women by employee category. \\
\hline \multicolumn{2}{|r|}{ Social Performance Indicators } \\
\hline \multicolumn{2}{|c|}{ 1. Aspect: Investment and Procurement Practices } \\
\hline HR1 & $\begin{array}{l}\text { Percentage and total number of significant investment agreements that } \\
\text { include human rights clauses or that have undergone human rights screening. }\end{array}$ \\
\hline HR2 & $\begin{array}{l}\text { Percentage of significant suppliers and contractors that have undergone } \\
\text { screening on human rights and actions taken. }\end{array}$ \\
\hline HR3 & $\begin{array}{l}\text { Total hours of employee training on policies and procedures concerning } \\
\text { aspects of human rights that are relevant to operations, including operations, } \\
\text { including the percentage of employees trained. }\end{array}$ \\
\hline
\end{tabular}




\section{Aspect: Non-discrimination}

\begin{tabular}{ll}
\hline HR4 & Total number of incidents of discrimination and actions taken. \\
\hline 3. Aspect: Freedom of Association and Collective Bargaining \\
\hline HR5 & $\begin{array}{l}\text { Operations identified in which the right to exercise freedom of association } \\
\text { and collective bargaining may be at significant risk, and actions taken to } \\
\text { support these rights. }\end{array}$ \\
\hline 4. Aspect: Child Labor \\
\hline HR6 & $\begin{array}{l}\text { Operations identified as having significant risk for incidents of child labor } \\
\text { and measures taken to contribute to the elimination of child labor. }\end{array}$ \\
\hline 5. Aspect: Forced and Compulsory Labor \\
\hline HR7 & $\begin{array}{l}\text { Operations identified as having significant risk for incidents of forced or } \\
\text { compulsory labor, and measures taken to contribute to the elimination of } \\
\text { forced or compulsory labor. }\end{array}$ \\
\hline 6. Aspect: Security Practices \\
\hline HR8 & $\begin{array}{l}\text { Percentage of security personnel trained in the organization's policies or } \\
\text { procedures concerning aspects of human rights that are relevant to operations. }\end{array}$ \\
\hline 7. Aspect: Indigenous Rights \\
\hline HR9 & $\begin{array}{l}\text { Total number of incidents of violations involving rights of indigenous people } \\
\text { and actions taken. }\end{array}$
\end{tabular}

\section{Social Performance Indicators}

\section{Aspect: Community}

SO1 Nature, scope, and effectiveness of any programs and practices that assess and manage the impacts of operations on communities, including entering, operating, and exiting.

\begin{tabular}{ll}
\hline 2. Aspect: Corruption \\
\hline SO2 & $\begin{array}{l}\text { Percentage and total number of business units analyzed for risks related } \\
\text { to corruption. }\end{array}$ \\
SO3 & $\begin{array}{l}\text { Percentage of employees trained in organization's anti corruption policies } \\
\text { and procedures. }\end{array}$ \\
SO4 & Actions taken in response to incidents of corruption. \\
\hline 3. Aspect: Public Policy \\
\hline SO5 & $\begin{array}{l}\text { Public policy positions and participation in public policy development and } \\
\text { lobbying. }\end{array}$ \\
SO6 & $\begin{array}{l}\text { Total value of financial and in-kind contributions to political parties, } \\
\text { politicians, and related institutions by country. }\end{array}$ \\
\hline 4. Aspect: Anti-Competitive Behavior \\
\hline SO7 & $\begin{array}{l}\text { Total number of legal actions for anti-competitive behavior, anti trust, and } \\
\text { monopoly practices and their outcomes. }\end{array}$ \\
\hline 5. Aspect: Compliance \\
\hline SO8 & $\begin{array}{l}\text { Monetary value of significant fines and total number of non monetary } \\
\text { sanctions for non-compliance with laws and regulations. }\end{array}$ \\
\hline
\end{tabular}


Product Responsibility Performance Indicators

1. Aspect: Customer Health and Safety

PR1 Life cycle stages in which health and safety impacts of products and services are assessed for improvement, and percentage of significant products and services categories subject to such procedures.

PR2 Total number of incidents of non-compliance with regulations and voluntary codes concerning health and safety impacts of products and services, by type of outcomes.

\section{Aspect: Product and Service Labeling}

PR3 Type of product and service information required by procedures, and percentage of significant products and services subject to such information requirements.

PR4 Total number of incidents of non-compliance with regulations and voluntary codes concerning product and service information and labeling, by type of outcomes.

PR5 Practices related to customer satisfaction, including results of surveys measuring customer satisfaction.

\section{Aspect: Marketing Communications}

PR6 Programs for adherence to laws, standards, and voluntary codes relared to marketing communications, including advertising, promotion, and sponsorship.

PR7 Total number of incidents of non-compliance with regulations and voluntary codes concerning marketing communications, including advertising, promotion, and sponsorship, by type of outcomes.

\section{Aspect: Customer Privacy}

PR8 Total number of substantiated complaints regarding breaches of customer privacy and losses of customer data.

\section{Aspect: Compliance}

PR9 Monetary value of significant fines for non-compliance with laws and regulations concerning the provision and use of product and services. 
Telaah Bisnis, Volume 14, Nomor 1, Juli 2013 